\title{
Book Review: The Life Space of the Urban Child: Perspectives on Martha Muchow's Classic Study ${ }^{1}$
}

\author{
Eileen Pfeiffer Flores ${ }^{2}$
}

Universidade de Brasília

\section{Resenha: The Life Space of the Urban Child: Perspectives on Martha Muchow's Classic Study}

\begin{abstract}
Mey, G., \& Günther, H. (Eds.). (2015). The life space of the urban child: Perspectives on Martha Muchow's classic study. New Jersey: Transaction Publishers
\end{abstract}

Hamburg, circa 1930. The great Karstadt department store building stands out majestically against the spring sky. A doorman carefully watches the comings and goings at the elegant entrance to the newly erected consumer paradise. A child distracts him with a question while another attempts to run inside. The doorman is not fooled and calls out sharply for them to come back: children are forbidden to go inside unaccompanied. Two minutes later, the same children appear, following two adults whom they claim to be their parents. The door attendant frowns but the children take advantage of his momentary hesitation and are inside before he can answer. From a nearby corner, a lean woman with vivid, inquisitive eyes watches the scene and takes notes on a pad, her lips insinuating an amused smile. Inside, a great variety of smells impinge on the senses of avid window shoppers: flowery hazes of French talcum blending in with the sharp scent from the sauerkraut barrels and the warm fumes from the pretzel kiosk. People swarm the corridors, some in a leisurely stroll, and others in hurried, nervous steps. The two children walk up and down the modern escalators in delight but pretend to be on an errand and ask for prices at a fruit stand as soon as they spot a suspicious guard looking at them. The lean woman follows them, observing carefully and taking notes.

The scene described above is only one of the vivid ones that came to my imagination as I read The Life Space of the Urban Child, the study conducted by Martha Muchow in Germany in the 1920's, now translated to English for the first time by Hartmut Günther. The translation of Muchow's study forms the center of The Life Space of the Urban Child: Perspectives on Martha Muchow's Classic Study. Chapters written by various researchers and edited by Günter Mey and Hartmut Günther surround this core chapter. Sections I and III bear on the study's historical context and its theoretical and methodological foundations, respectively. Section IV offers perspectives for research inspired in various ways by the Life Space study.

1 The author thanks Isolda de Araújo Günther and Timothy Mulholland for their valuable comments and suggestions

2 Endereço para correspondência: Departamento de Processos Psicológicos, Instituto de Psicologia, Campus Universitário Darcy Ribeiro, Brasília, DF, Brasil.CEP 70910-900.E-mail: eileen@unb.br
Martha Muchow's brother first edited and published The Life Space of the Urban Child in 1935, after her tragic death. He introduced his sister's work by noting that scientists had achieved very little understanding of children's lives in the cities. Since most researchers were urban dwellers, they had little consciousness of their surroundings. As the saying goes, "the fish do not see the sea". Hans Muchow also noted that the few studies existing at the time did not try to capture urban life as lived by the urban child. Rather, they spoke of child development in a void, as if it were possible to speak of such a thing as a general or universal childhood. Martha Muchow, on the contrary, strove to understand the concrete experience of the urban child of her time, as the child experienced it.

Muchow studied children from a working-class neighborhood (Brambeck). At first, she collected data on the relation between children and their space in the more traditional sense: the "Space in Which the Child Lives". She used maps of the city and asked children to mark places they knew well, less well or not at all and to describe where they played, worked, studied, went on family outings and roamed, as well as the boundaries of their explorations, with and without adults. She then moved on to the "Space That the Child Experiences". Using interviews and autobiographical essays, she asked children about their preferred play spaces and activities in different parts of the city. Finally, she investigated "Space, as the Child Lives it". This is perhaps the most important and innovative part of her work, which offers glimpses, captured through multiple creative methods, of urban spaces as they are lived, in the transitive sense, by the child. Thus, for example, she first described a loading dock in its functional aspects, as planned and used by adults. She then contrasted this functional aspect to how children took hold of the space and actively made it theirs. Using various observational and sampling techniques, Muchow showed how dimensions of the Hamburg loading dock, which were virtually invisible to adults (because they played no role, or solely a specific functional role, in the adult world) were appropriated by children in various unexpected ways. For example, adults perceived a grid that separated a sidewalk from a loading dock as an obstacle that prevented falls and ignored it as they walked by. For children, on the other hand, it was practically the opposite: a very inviting stimulus that called for various forms of movement, such as touching, 
brushing the grid with a stick while walking by to produce sounds, climbing to the other side, etc. Muchow described how small children used the grid as an opportunity for separating themselves from adults for a while, as they let go of the adult's hand and walked a bit of the way on the other side, all the while in sight of the adults, on a kind of "safe adventure".

One of the most interesting aspects of Muchow's work, reflected in Hartmut Günther's thoughtful translation, was the transparency of her methodological and conceptual thoughts on the difficulties of observing everyday life. In several places, she stopped to consider the limitations of her methods and the difficulty of studying the "infinitely small, partial spaces which enter into the personal world of the children" (p. 143). She also considered the perils of judging the child's world by adult parameters. As expressed by her brother Hans Muchow in his Preface, there is no city independent of those who experience it, and the big city as an independent entity is only a fable convenue.

Hartmut Günther includes a chapter on his experience of translating Muchow's study from the viewpoint of an environmental psychologist. He notes that many of the resourceful methods used by Muchow, such as asking the children to write essays or to signal places they knew on a map, were new at the time and are still very relevant today in studies of environmental and developmental psychology. Muchow's work is still innovative, creative and relevant to present day methodological and theoretical research issues for psychology, as well as other social sciences. It is therefore surprising that only now should we receive a first English translation, nearly eighty years after its original publication. As we learn more about Muchow's work, we realize that the story of this forgotten study is also the story of much psychological research that fell into oblivion after the Second World War.

This becomes clear in the first section of the book, composed of three essays on the historical background of Muchow's study. The chapter by Imbke Behnken and Jürgen Zinnecker tells the story of how Muchow's work disappeared after her death, as well as many other important works produced in the psychological laboratory where Muchow worked with her teachers William Stern and Heinz Werner. Jürgen Zinnecker recovered Muchow's study and published a reprint in 1978. Successive German editions came out thereafter. Behnken narrates (Zinnecker died in 2011) how she and Zinnecker embarked on a historical voyage through Muchow's Hamburg and its transformations, in their quest to understand why such groundbreaking work remained forgotten for so many years. They tell a poignant story of deliberate interruption and destruction of scientific work, inseparable from the interruption and destruction of countless lives during the Nazi regime. One of those lives was Martha Muchow's, who committed suicide when the Nazis took power, unable to bear the cruelness and hostility that took over the university and German society in general.

The second chapter of the historical section, by Kurt Kreppner, situates Muchow's biography in the wider context of the Weimar years and a widespread enthusiasm for youth, youth movements and educational reform. Martha Muchow wished to contribute to a better understanding of working class children. One of her most important aims was to help teachers obtain the most from each child's potential, especially working class children. One of her preoccupations was to develop tests and training methods to help teachers improve observation skills. Such skills would allow teachers to recognize and develop workingclass children's special skills and talents. This was in line with the aims of the Psychologische Institut, where Muchow worked and researched during her short career. The Institute, born out of the previous Laboratory for Youth Studies, laid a heavy emphasis on pedagogical studies, and stressed the importance of scientific psychology for educational reform. Muchow said that if we wish to understand what goes on in the school setting and thus improve education, we should focus, not on the child, but on the complex and reciprocal relations between child and environment, including, of course, the teacher. Unfortunately, this point of view has still to become predominant, as pathology-centered views of the learning process continue to gain terrain. In Brazil, for instance, Ritalin prescriptions for schoolchildren have been on an alarming rise (dos Santos, da Silva, Luzio, Yasui, \& Dionísio, 2012).

Elfriede Billmann Mahecha completes the historical section of the book with an interesting comparison between Muchow's Life Space study and three contemporary studies. An early documentary by Kurt Lewin is mentioned by Mahecha as an example of minimum contrast to Muchow's work. Lewin, like Muchow, collected many hours of close observation of children's movements and interactions with the environment and offered complex depictions of how children transform and are transformed by the world around them. A study by Hildegard Jüngst with young female factory workers serves as an example of Muchow and her contemporaries' surprising consciousness of the pitfalls and dilemmas of participant observation. On the other hand, Jüngst's study is also an example of opposing ideological forces at work during the Weimar years. While Muchow showed an admirable respect and non-judgmental attitude toward her participants and clearly wished to contribute toward a more just society, Jüngst described participants as inferior in many ways and steered her research toward more conservative conclusions. A last comparison with Siegfied Bernfeld's psychoanalytical account of friendship and sexuality among young girls serves as an illustration of the variety of theoretical lenses and especially as an example of the multiplicity of methods (e.g., diaries, biographies, sociograms) characteristic of research during the Weimar years.

The section devoted to the theoretical and philosophical foundations of the Life Space study begins with an insightful analysis by James T. Lamiell of how William Stern's personalistic framework for the study of human beings marked Muchow's work in very fundamental ways. Stern was not forgotten, as Muchow was, but he was remembered for reasons he did not care for (the IQ measure, for instance; Lamiell, 2003). One idea dear to Stern was that human activity cannot be explained solely or even mainly through the discovery of effective or moving causes. According to Stern, effective causes are relevant only when the subject is in a relatively closed setting and presented with a limited number of stimuli to which it must react. It is when the 
subject is acting freely in a complex environment that the psychologist has the best chances of understanding behavior. Such spontaneous behavior is best explained by what Aristotle called final causes. In Stern's view, science should not shun final causes but embrace them and elaborate them conceptually and methodologically. Since spontaneous, purposeful behavior is best studied by observational methods, experimental studies should complement, not replace, the careful and detailed observation of behavior in natural settings. Lamiell shows the deep resonance of these ideas in the Life Space study. Finally, Lamiell explains that the fundamental unit of analysis, for Stern as well as for Muchow, was the whole person. Their main argument was that sciences might make a distinction between body and mind for matters of theorizing or empirical research, but the mind-body distinction itself presupposes the concept of person. In other words, the concept of person is prior and necessary for the mind-body distinction to make sense, and not the other way around. The environment, in the same manner, cannot be seen as a separate realm. The person-world convergence is primary and the world as an objective, physical mathematical world is a conceptual derivation created by scientists for their specific purposes. Muchow, as we have seen, adopted the person-world convergence as a premise.

The last two chapters of the "Foundations" section show that the phenomenological stance was part of the zeitgeist in Hamburg at the time when the Life Space study was undertaken. The chapter by Lauri Linask, Riin Magnus and Kalevi Kull describe the work of the biologist Jacob von Uexküll, who led a laboratory in Hamburg and defended a general outlook shared by Stern and other contemporaries. Uexküll studied non-human species and asked how the environment invited different actions depending on each species' "building plan". Different species are equipped with different physiological instruments that permit them to grasp different aspects of the world. In this sense, it is incorrect to say that they to adapt to the same environment, for the environment is not independent of the organism. Linask et al. argue that Muchow parallels this reasoning on the ontogenetic level. Children in different developmental stages experience different worlds, largely because of different constraints and possibilities imposed by their bodies at each stage.

Peter Faulstich and Hannelore Faulstich-Wieland make the phenomenological underpinnings of Muchow's work even more explicit by analyzing how Muchow looked to Edmund Husserl's ideas in her quest to overcome the classic description versus comprehension dichotomy. They point out, however, that, for Muchow, phenomenology was always an instrument for conceptual elucidation rather than a set of methodological recipes. For her, a theoretical framework was something that helped to clear conceptual ground but did not dictate methodological strategies.

The book closes with a section on perspectives for research and theory inspired by Muchow's study. Urs Fuhrer considers how developmental and environmental psychology have been linked in several classical and contemporaneous approaches. For instance, developmental studies in different decades have agreed on the enormous importance of unstructured play environments for healthy child development (e.g., Fjørtoft \& Sageie, 2000). In the last three decades, however, there has been almost exclusive emphasis on social milieu in developmental psychology, with little consideration of other environmental factors. Fuhrer laments that integrative proposals such as Martha Muchow's did not have the deserved impact on research.

Günter Mey presents contributions of Muchow's methodological innovations to qualitative research, understood not merely as a gateway to quantitative analyses or as an exploratory strategy, but as a methodological choice in its own right. He discusses how the Life Space study pioneered method triangulation, which is very important in developmental studies, not merely as a way to replicate results but as a strategy to enrich description and to capture the child's viewpoint by gaining insights from various sources. Especially interesting in this context is Muchow's use of contrasting situations as a sampling strategy: a playground especially designed for children versus a vacant lot, a busy commercial street versus a quiet residential street, etc. The use of maps, interviews, various forms of observation and essays contrast with the majority of studies today, which usually limit themselves to a single method of data gathering. One cannot help thinking about how much this has to do with current pressures and demands for faster data and publication, and how much is potentially lost in the process.

Muchow was ahead of her time concerning how she treated her research subjects, striving for methods that avoided imposing the adult's point of view and favored really listening and striving to understand children's experiences from their standpoint. Beatrice Hungerland discusses changes in how developmental researchers perceive childhood. Views of children as passive recipients of education, as adults-tobe, gave way to views of children as social actors in their own right. Even so, as Hungerland points out, research with children is usually conducted by adults and serves to answer adults' questions. Even when children help to build research and interpret results, they are somewhat limited in this freedom and follow to some measure what adults expect.

The importance of avoiding an excessively naïve viewpoint of the child's appropriation of the environment is also evident in Gerold Scholtz's chapter. He argues that any approach that relies exclusively on the subject's experience of the environment may not be sufficient to capture its most relevant features. Scholtz's main example is the classroom, a space often ignored by environmental and childhood studies, although children spend a very great portion of their lives there (Muchow, for instance, did not observe children in this setting in the Life Space study). Educational studies focus on teaching and learning outcomes but seldom approach children's experiences in the classroom environment. As Scholtz suggests, it is necessary to bridge these points of view in order to understand the relations between the child and the pupil as sociological categories. However, he warns that there are limitations to what we can discover solely by observing children in the classroom. To understand how they experience the classroom environment, we first must understand that it is a space which expresses the educational values, goals and presuppositions of what adults consider an adequate education, independently of its perception by children. Therefore, solely listening to what children have to say (through interviews, essays, etc.) is not a window 
onto spatial, social and power relations that shape the school environment. It is much more an expression of what children think adults expect them to say. Scholtz thus underscores the need for deeper dialogue between environmental and developmental psychology.

Kristin Westphal closes the commentaries on the Life Space study from a different angle as she reflects on space and embodiment in Muchow's work and its relevance to understanding our relations to space today. Muchow's operative concepts for the interpretation of how different groups moved and interacted with the environment in a large shopping center are still relevant today, although the specific examples will, of course, be different. Muchow observed that teenagers interacted with technological innovations of the time by using them in non-conventional ways and playfully acting against their planned purpose (by walking up a descending escalator, for example). These subversions of the technological order serve to highlight, as an exception to the rule, how public spaces usually constrain our bodies and create stereotyped and ritualized movements. This consciousness of how body relates to space was present in the art of Muchow's time. For example, drama ceased to be seen as the simple acting out of two-dimensional text and began to be seen as the interaction of bodies in tri-dimensional space, including the relationship of actors with with the public. Westphal concludes with a reflection on how this modern conception of body and space, evident in Muchow's work, can be extended to apply to virtual spaces, so prevalent and central in children's lives today.
In Brasilia, the city where I grew up, residential buildings were planned by Lucio Costa to be no more than six stories high. His idea, so the legend goes, was that places where people lived should never be so high as to prevent the human voice from reaching someone on the ground. During my childhood, we spent much of our time roaming the superquadras (planned residential blocks) on our bikes, climbing trees or playing ball games with no more adult supervision than an occasional call from the window to come up and have dinner, do our homework or take a bath. Today, there are very striking changes in the environments in which children are growing up. In many urban and rural settings, there has been a frightening decrease in opportunities for children to roam freely and to explore and manipulate nonstructured spaces, with many of them spending whole days in extremely structured settings. Psychology can contribute to the understanding of how bodily experience of space and time is to be translated in this new scenario, where real and virtual spaces intersect and notions of distance and time are profoundly modified. Now, more than ever, Martha Muchow's theoretical and methodological innovations can contribute to our understanding of the relationships between children and a changing world.

\section{References}

Fjørtoft, I., \& Sageie, J. (2000). The natural environment as a playground for children: Landscape description and analyses of a natural playscape. Landscape and Urban Planning, 48(1), 83-97. doi: 10.1023/A:1012576913074

Lamiell, J. T. (2003). Individual and group differences: Human individuality, scientific psychology and William Stern's critical personalism. Thousand Oaks: Sage.

Santos, K. Y. P., da Silva, A. C. P., Luzio, C. A., Yasui, S., \& Dionísio, G. H. (2012). A explosão do consumo de Ritalina. Revista de Psicologia da UNESP, 11(2), 44-57. 